\title{
見よう見あね
}

\section{Self-Discipline under the Spartan Leadership of Predecessors}

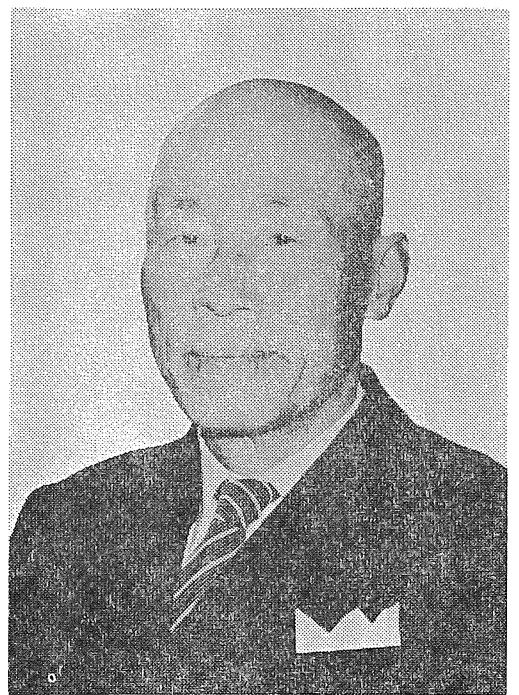

世の中は日に月に進歩し，それを背負ら世代子急に 若返って力強さを增し，大いに期待されているわけで ある。その中で，私などの言葉は少し不似合いとも思 われるが，温故知新とでも逃げて和くことにする。私 は，自分が学校を出て入社したころを思いだし，昔と 今の育て方とか，しつけとかについて書こうとしたが， 肝心の今のことが良くわからないので, 結局平凡な私

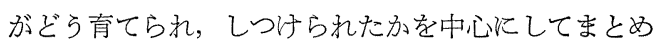
ることにした。

ある雑誌 (東洋経済) に老社長談として，「この頃の 新入社員は標準化されて個性がない」とのことが載っ ていた。これは学校のカラーが少なくなったことかも 知れないが，こういう言葉を聞くと，なるほど世の中 はコンピューター時代に進み, オートメーション化, マスプロとそらいう進歩にふさわしい学校教育かなと 思った。

私たちの時代は縦割りの組織で, 上司の権力は絶大 であった。日々の仕事でる, 己れについて来いという 勇敢さと自信に充ちた先輩振りで，特別の講義による 教育はなかった。そこで先輩の働き振りを見よう見ま ねで，自己啓発に努めるということになり，一方では

脚注 本州製紙株式会社副社長 北日本製紙株式会社社長
王子製紙株式会社顧問 山 内 聁

Satoshi Yamanouchi Adviser; Ōji Paper Co., Ltd.

スパルタ式とでもいうか，厳しくしつけられ，小言も 大へえ多かった。それで私などは一つの悟りのような 手前勝手な理屈を持つよらになった。見て覚劣るのは 自発的な教育であり，此られることは上司から教光て 貪っているんだと。だから小言は貴重なるのなんだと 自分に言い聞かせていた。だがあんまりやられると良 、気持ちはしなかった。それがあたうまくこっちのッ ボを突いてるからなる汪どと思いながらもこた觉るわ けだ。同僚の中には，さっさと逃げ出した男もいた。 工場長がその後で, 今の学校出の者は意志が弱くて困 る，折角役に立つ人間育ててやららと思って，少し きびしくすると会社をやめて行ってしまらと，しんみ， り話されたことを覚えている。実はこちらも内心ビク ビクの時代であったから泠汗もので承っていた。縦割! りの組織というものは, 私などの育った頃は良かった なと思う。よく注意されるので虾互の責任もはっきり してるよらに考光られ，上下が親しくなり，温かい血 のつながりが感じられた。工場でうんと鍛えられた後 などには，今夜一杯飲みに行こうなぞと誘われ，同僚 と一緒にご馳走にあやかったことも再三であった。ま た本社などにも工場長が適当にP Rしてくれてるらし く，まじめにさ兄やって和ればどこかで誰かが見てい て，出世などとは手の遠い所とよそごと思っていて も時期が来猄ば，何かにありついてビックリすること も西った。これは後々になっても何回かそらいらチャ ンスにめぐをれて，先輩の方々には終世忘れ得ない感 謝となって身にしみ込んでいる。これが会社の䁔かい 伝統の一つかとも思う。

私が旧王子製紙に入社したのは大正 7 年と大へん古 い昔になってしまった。入社試験もなかった，一面暢 気な時世でもあった。最初に勤務したのが今の十条製: 紙の十条工場で，政府から大正 5 年に譲り受けたもの で 100 in マシン 1 台で官製八ガキと模造紙 (今の上質 紙の前身)を抄造していた。これを2号マシンと呼び 1 号マシンを建設中であった。周辺が田围だったので 「田圈の工場」と呼ばれていた。私はここで 23 年訓練: を受け，ぞんなことを身につけたか述懐して見たい。 十条工場では 2 人の工場長の指導を受けた。始めの工 場長は堀越寿助さんという方で，まことに大人型で， 
最初招会いした時はビックリしてしまった。学校の主 任教授の親友で, その先生の人物評は「堀越君は一度 部下にした男はいつまでも面倒を見るという型の男 だ」と聞かされ，ある希望をもって，九州からの途中 工場に寄ったわけだったが，初対面では笑顔一つ見ら れず，ビックリして早々に引きあげて国に帰ったが， 会社といらところは大へんな所だなと沈んだ思いであ った。

こんどは勇気を出して上京し， 2 度目に会ったとさ は本社への紹介状を書いて下さったりして様子が変っ て来たのでホッとした。日がたつにつれてわかったこ とだが大へん親切な方で本を読め，外国䧴誌を読めと か，見学に出しては報告を書けと何かと世話をしてく ださった。その度に文の訂正や，和前は字を知らない とか注意された。その声が大きいし，ポカッと来るの で叱られているようでもあった。 1 年ほどで，大阪の 都島工場飞重役として栄転されたが，見送りのときは 寂しい思いであった。

この 1 年がご縁となって，その後もながく何とはな しに目をかけていただいた感じで，先生が言われた通 り部下の教育に熱心な方であったことを有り難く思っ ている。この方の工場管理で最も印象に残っているこ とは，個人の身だしなみやエチケットに始まって工場 の美化に及び，工場の整理整頓にはことのほか厳しく， 大した雷親父さんでもめったから，従業員全部が括こ られない上らに，毎朝工場に入られる前に一生䯚命掃 除をした。らまく整理整頓することは簡単なようだが， やって見ると中々。工場の作業そのものが順調であっ てこそ初めて出来ることで，見せかけだけのるのはす ぐバレてしまうもので，まことにうまい管理方法だと， 堀越さんを思い出すたびにその小言がなつかしい。

堀越さんは王子の重役加旭鉄工所社長，日本金網 社長を歷任され，これは後のことだが私も縁あって， 都島，旭鉄工所，日本金網に在任したことがあった。 その行く先きざきで大人の愉快な逸話を面白く承わっ た。戦後王子製紙 3 分割の翌年 82 才の長命で大往生 された。

堀越さんの後を引き継いで工場長になられたのが西 済さえ (現紙パ技術協会長) であった。西さんはこの 工場払い下げに当って調查業務にたずさわり，次いで 工場代理から大正 8 年工場長に進まれたので，工場に は馴染及深い存在ではあったが何分工場の隅々まで知 り過ざて扮られたので，みんなピりピリしていた。

既設の 1 台のマシンに加えて増設に次ぐ増設で，10 :年ばかりの間に 5 台の新マシンが設置され，その度に 新しい式を取り入れ，十条工場を苫小牧に次ぐ工場に
育て上げられたことは西工場長の大きな功績であった。 仕事熱心で勉強家で，データはキチンと整備して招ら れ，その上実行が早く，年は 34 5才で働き盛かり。 われわれが相当努力したつもりでもギャップができて， みんなかわるがわるよく叱られたものだった。しかし 気楽な一面はあった。それは人の好き嫌らいがない， 仕事する人が好きということ，また私交上の心らかかい なんか何乎要らない，従って招互同志も簡略。外のこ と飞余計な気をつがう必要がない。だから私のような 気のきかない男には上からの指図通り仕事さ光まじめ にやって抢机ばよいので，頭の整理が常に単純でよか ったことが大へん有り難たかった。

西さんの工場管理に二，三とくに感じたことは，工 場の音響傜特別のリズムを感知して执られたようで， 夜中社宅に伝わって来る音の具合で，昨夜仕上室の音 がとか，1号マシンの音が違っていたが何かあったか といらようなことが何回となくあった。また社宅から 正門を入るまで煙突の煙を見る。この工場に適した 煙の色を頭に入れて抢られる。それが薄いとか濃いと かで，作業情況を判断される。ボイラーマンもだんだ 几上手になって先き回りするようにはなった。

しかし難問題として日々力を入れられたのはマシシ の排水，流失原質対策であった。毎日工場に入られる 前北立ず排水溝をのぞかれる，排水がき机いなとき は工場の外まわりから工場全体を回わり，水が濁って でもいるとすぐ各マシンのパルプセーバー（白水の 沈殿槽）に上がって悪い所があれば，ご自分で指図を して直されるといった熱の入れよう。このセーバーが 抄造課と原質課の泣き所で，マシンの調子が悪いと荷 が重くなるからてき面濁って来る。また調成の方で 使い方が悪いと，これもひびいて来るといらわけで， マシンの排水を管理していると工場の作業全般にわた って管理出来ると言いらるのであった。

試験室では排水量と原質の流失量を日に 2 回計り, 同時に排水の透明度を計って報告していた。相当うま くいったと思っても，1 か月平均して見ると，流失量 が抄造高の $1 \%$ 以下にすることは中々むづかしかった。 こういう徹底した管理は工場全員の頭にしみ达んで, 安定操業と歩留り向上に貢献したことは甚大であった。

こんな具合に工場長の管理方式を見ていると，1つ がうまく行くことは全般が調子良くいっていることに なり，ま㐫一事が万事だなと，つくづく感じたことで あった。

堀越工場長は整理整頓, 西工場長は流失原質(歩留), 私は十条工場に 28 年間, 見よう見ま水によって, 工 場管理は一事が万事だと自分勝手の理論を習得した。 
その後小倉工場, 都島工場を歴任し, 工場生活約 30 年を終わり, 昭和 22 年本社戻され, 王子, 本州, 日本金網と，14 年の本社生活中に北日本製紙の再建 ということになり，37年 9 月，そちらに就任するこ とになった。勿論自信があるわけでもなし，当って砕 汓ろ式の気持ちであった。

この会社は 1 社 1 工場だから, 工場をうまく運営す る以外飞金の入る道はない。また金融の具合で設備増 強もでさない。さし当りは「現在の設備をもって何処 まで利益を生み出せるか，全員の協力だ」といら掛け 声で再建のスタートをした。私もでさるだけ工場に出 向くことにしていたが，なにぶん 5 年のブランク（日 本金網在任）で時世も大きく変わり機械も進歩してい るし，急には口出しもできなかった。それでも，仕上 室を見たとき，これは昔と同じようなものだし，これ なら助言がでさると元気づいた。元来仕上げ作業は紙 を検査して悪い製品を工場の門から出さないこと，ま た検査の結果を抄造部門に連絡し，あい共に品質向上 努力して増産に寄与するという，大きな責任の場所 であるべさだと教えられて来たが，実際は抄造部門の アクセサリ一的存在に扱われ，抄造課長が片手間で世 話をしている工場もあるようだ。北日本製紙も両更ク ラフトの次に上質に入ったから，どうも仕上げが遅れ
ている感じがした。私は第 1 亿仕上げ作業を見つめる ことから押し進めて行くこと決めた。ちょらど友人 の仕上げ専門会社（尼が崎製紙）が成績を上げている のを聞き，仕上げ女性を 10 人位の組にし，毎年 1 組 づっ, 3 回程指導を依頼した。これは大変有効であっ た。そんなことで工場でも認識を深くして, 興味が出, 仕上げを重視するようになり, 逐次設備が強化され, 自動包装機をはじめ, 選別台の工夫とか, 新味が加觉 られることになった。私も行けば毎日仕上室を回わっ て激励した。仕上げ女性とも近しくなり, 紙の話も通 じるようになった。また製造部門にも仕上げの話が尊 重されることになり, 仕上室全体が活気づき, 紙に対 するユーザーのクレームも減って来た。製造部からは 代わるがわるユーザーの現実の声を聞くように回わっ てもらった。こういうことが工程全般にも良い結果を もたらし，増産の一端をになうことができたと思って いる。私の一事が万事理論が自己満足に過ざなかった かどらかは工場幹部の批判を待つ次第である。

しかし会社全体が一つになって，相協力した 8 年間 の努力が実のって，45 年 9 月王子製紙に合併しても らうことができたのも，先輩の方々の暖かい血のつな がりと，色々とお力づけくださった結果なんだと深く 感謝して抒ります。

\section{新刊紹介 \\ 昭和 44 年 \\ 紙・パルプ工業設備調査報告畫}

（昭和 44 年 12 月末日現在）
昭和 46 年 3 月 31 日発行
442 頁
頒価 3,000 円
編 集通商産業大臣官房調査統計部
発行所 紙・パルプ連合会

\section{第 1 編 概 況}

第 1 章: 総 合 第 2 章: パルプ製造設備 第 3 章: 紙製造設備

\section{第 2編 統計}

I : 総合統計 II：パルプ製造設備統計 $\mathrm{II}$ ：紙製造設備統計

\section{第 3 編 工場別製造設備能力}

$$
\text { I : パルプ III: 紙 }
$$

付録 I : 紙・パルプ製造設備調査記入要領

付録 II：企業および工場名簿 